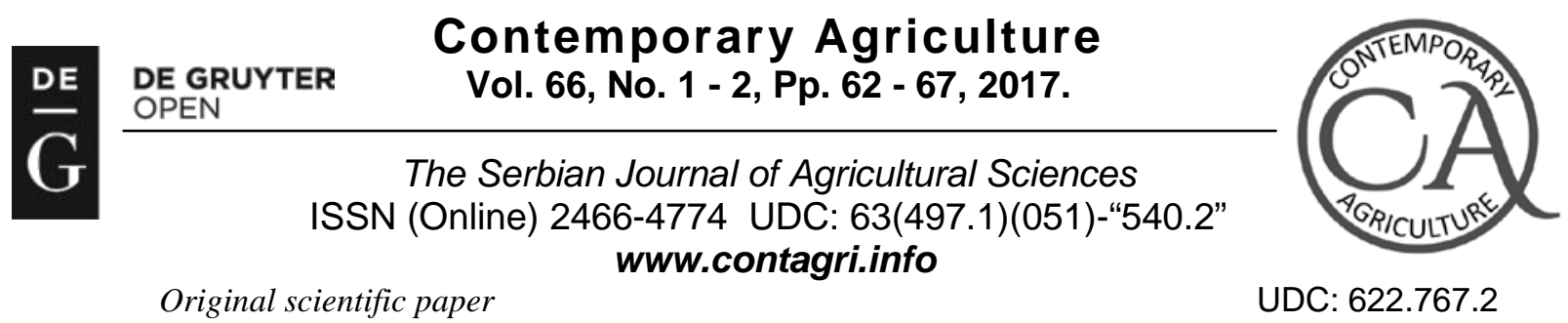

Original scientific paper

DOI: $10.1515 /$ contagri-2017-0011

\title{
POTENTIAL OF AGRICULTURAL BIOMASS: COMPARATIVE REVIEW OF SELECTED EU REGIONS AND REGION OF VOJVODINA
}

\author{
Petrana ODAVIĆ ${ }^{1}$, Dragan MILIĆ ${ }^{2}$, Vladislav ZEKIĆ ${ }^{2}$, Nedeljko TICA ${ }^{2}$
}

Summary: Owing to the fact that the EU is committed to reducing greenhouse gas emissions by $20 \%$ below 1990 levels by 2020, and having in mind their high dependence on import of oil and oil derivatives, which, in turn, causes instability of power supply, increasing attention is being paid to renewable energy sources. Given the ongoing pre-accession process of the Republic of Serbia in relation to the EU, in order to determine the capacity of the country to increase the share of energy use from renewable sources, in this paper clustering of selected regions in the EU-28 has been carried out, after which a comparative analysis of regions was performed in terms of potential of agricultural biomass, for the purpose of generating energy. The aim of this study is to determine the level of the region of Vojvodina in relation to ten selected EU regions, based on parameters that affect the potential for using renewable energy sources, primarily residues from agriculture. By applying the K-means method, Borda count method and comparative analysis, and based on empirical data, results show that the region of Vojvodina takes a significant fifth place. Its share of agricultural land ranks it as the first, whereas production of cereals and the total number of farms larger than 100 ha rank it as the second. It could be concluded that Vojvodina is an agricultural region with large quantities of plant remains, primarily those left over from harvest, which represents a significant potential for energy generation from agricultural biomass.

Key words: renewable energy, biomass, potentials, comparative analysis

\section{INTRODUCTION}

Owing to the diversity of its countries, but also by creating a union of countries, Europe has become an excellent area for a comparative analysis of developed countries in which the market economy functions relatively well, in contrast to „new“ EU countries - Central and South-Eastern Europe countries which have gone through a complex process of transition. For the purposes of this research, the focus is on the regional dimension, which includes similar natural and geographical advantages of certain regions for development of agricultural activities, as well as different levels of economic development. Previous research (Brkic, Janic 2007, 2010, 2011) examined that the total potential of biomass in Vojvodina is around 9 million tonnes per year. It is also concluded (Zekic, Tica 2007) that the agriculture of Vojvodina can produce different types of biomass specially harvest remains, or small grain straw. The challenge that EU regional policy faces in the coming years is establishing cohesion of regions and promoting harmonious, balanced, and sustainable development of EU regions, taking into account the differences of each. The regionalization of countries is done primarily to facilitate the use of numerous data for individual countries, and it is the instrument, i.e. mechanism used for statistical purposes. It should be known that economically use of biomass for energy production is only possible with state subsides in the form of feed-in tariffs (Official gazete RS, 2016).

This classification is a hierarchical system for dividing EU countries into economic territories for the purpose of data collection, development and harmonization of regional statistics, as well as for social and economic analysis of the region. The EU member states' aim is to reduce greenhouse gas emissions by $80-95 \%$ below 1990 levels by 2050, while the Union's strategic target for 2020 is reduction of GHG emissions by 20\% below 1990 levels (EC Directive 2001, 2003a, 2003b,2009). On the other hand, the dependence of the European Union on import of oil and oil derivatives is prominent, with as much as $87.9 \%$ of the total consumption in 2013 being imported (Eurostat 2017). Import dependency can cause serious problems in stability of energy supply, while negative experiences in international energy markets and unexpected oil crises give priority to renewable energy sources. The share of renewable energy sources in gross final energy consumption is a key indicator for measuring the improvement of the level of each individual EU member country. A possible solution in terms of addressing problems of meeting energy

\footnotetext{
1 Petrana Odavić, M.Sc., Advisor for fiscal and macroeconomy analysis at Provincial secretariat for finance, Government of Vojvodina, Bul. Mihajla Pupina 16, 21000 Novi Sad, +381603999669, e-mail: petrana.odavic@gmail.com

2 Dragan Milić, Ph.D., Vladislav Zekić, Ph.D., Nedeljko Tica, Ph.D., Associate Professors, University of Novi Sad, Faculty of Agriculture, Trg Dositeja Obradovića 8, Novi Sad
} 
needs, as well as compliance standards in the field of environmental protection, is increased use of energy from renewable sources. One such source is agricultural biomass.

\section{MATERIAL AND METHOD OF THE STUDY}

Having in mind the ongoing pre-accession process of the Republic of Serbia in relation to the EU, in order to determine the capacity of the country to increase the share of energy use from renewable sources, a clustering of selected regions in the EU-28 has been carried out, based on natural, geographical, and agro-economic parameters, and corresponding to NUTS-2 (Nomenclature of Territorial Units for Statistics) level of classification, after which a comparative analysis of regions was performed in terms of potential of agricultural biomass, for the purpose of generating energy. Under the National Renewable Energy Action Plan for 2013, Serbia's strategic target is for the share of use of renewable energy sources in total energy to reach $27 \%$ by 2020 . This work is part of the research which defines real physical potential for biomass conversion in Vojvodina, for agricultural holdings whose area is larger than 5 hectares. For the purposes of determining the total real potential, as well as rational and economically viable use of agricultural residuals in energy production in Vojvodina, agricultural area of holdings, agricultural production (crops, yields), animal production (types, LSU, numbers), production technology and legislation were used as sources of data. Period of research is based on the last official data obtained from relevant institutions from 2001 to 2015.

Nomenclature of Territorial Units for Statistics has been developed and regulated by the European Union. For each member country of the EU there are three NUTS levels defined by European Statistics and marked according to special rules. The criteria used for grouping are determined by European Union standards, which include population, geopolitical position, natural resources, existing territorial organization, as well as cultural and historical heritage. The same statistical system is defined for the candidate countries for EU membership, which also includes Serbia. Vojvodina is a lowland region in northern Serbia, with mild climate, where more than $90 \%$ of the land is used for agricultural purposes. The nomenclature of the region is statistical help for assessment, analysis and comparison of data and should be as accurate as possible.

The study applied methods that can be grouped as follows: empirical and descriptive statistics with certain statistical and mathematical methods of calculation, comparative analysis, K-Means clustering method and Borda count method. To determine the position of the region of Vojvodina among selected regions of the EU using comparative analysis, clustering algorithm by K-mean values (MacQueen, 1967; Forgy, 1965) was applied. The most commonly applied technique is Lloyd's algorithm (Lloyd, 1982). Borda count method (Wei-Wen, 2011) is used to facilitate decision-making, distributing options in accordance with their rank sum.

For the purposes of this study, which is a part of the doctoral thesis research, in which is explored biomass from agricultural crops and also biogas production from livestock residuals, analysis was based on the latest official data of European and national statistics for individual parameters relevant to the field of biomass use from agricultural production. Those are: the share of arable land in total land (\%), total cereal production (million t), average cereal production $\left(\mathrm{t} \mathrm{ha}^{-1}\right)$, total number of holdings, number of holdings with area larger than 100 ha, the average size of holdings (ha), the total standard output of holdings (million $€$ ), number of holdings that generate renewable energy, livestock production (000 cattle), average number of cattle per holding, and number of livestock unit (LSU in 000). For the purposes of establishing the overall actual potential, as well as for rational and profitable use of by-products from agricultural production in energy generation in Vojvodina, the following were used as sources of data: surface area of plots and manner of using them, agricultural production (crops, yield), livestock production (types, livestock unit, number), production technology, and legal regulations.

Selected NUTS-2 EU regions have over 50\% share of crop farming products in the overall Gross Domestic Product (GDP) from agriculture. Regions that are selected by cluster analysis are as follows: South-East Bulgaria BG34, Central Bohemian Region Czech Republic CZ020 (Van Dama, Faja 2005; Lewandowskia et al., 2006)., Brandenburg Germany DE4 (Gutzler et al., 2015), Central Macedonia Greece EL52, Centre France FR24, Continental Croatia HR04,Veneto Italy ITD3, Southern Great Lowland Hungary HU33, Styria Austria AT22 and North-West Romania RO11.

\section{RESULTS AND DISCUSSION}

One of the deciding factors is agricultural land that is defined as arable land by the Food and Agriculture Organisation (FAO). Arable land is the land under permanent crops or under permanent pasture. According to new classification of the Republic of Serbia, used agricultural land includes garden fields, infields, arable land, meadows, pastures, permanent crops - orchards, vineyards, and nurseries. Comparison of selected regions of the EU and the region of Vojvodina in terms of the potential for use agricultural biomass in generating energy, is a challenge for experts, primarily because assessments can be performed in different ways, and certain data are not comparable to the same extent as others, since they are adapted to national contexts.

Based on the result that $73 \%$ share of arable land in the total land, comparative analysis ranks Vojvodina first among selected regions of the EU. It is followed by the Central region of France (59\%) and neighbors: Northwestern region of Romania (57\%) and Southern Great Lowland of Hungary (52\%). (Table 1). 
Having in mind the fact that cereal production is one of the most dominant and most important segments of agricultural production in the world, in addition to being the basis for food security of the population, it represents a significant potential in the post-harvest residuals that can be used for their conversion into energy. After analyzing cereal production by selected regions, Vojvodina takes second place, after the Central region of France (8.8 million tons), which is also the largest area among the selected regions. If the production of cereals is analyzed per agricultural arable land of a region, Vojvodina (3.95 $\mathrm{t} \mathrm{ha}^{-1}$ ) exhibits the second greatest agricultural potential in biomass, immediately after the Veneto region.

The level of development of regional agricultural activities is also influenced by the number and structure of agricultural holdings (Paraušić, Cvijanović 2014). A region that has a smaller number of holdings with a higher average utilized area is considered a more developed region. Vojvodina has around 150,000 registered holdings, with average area of about 11 ha in contrast to the rest of Serbia, where the average is around 4-5 ha. After analyzing the results obtained through comparative analysis of selected regions based on the above factor, it was concluded that Vojvodina still has a large number of small farms. According to this parameter, the Northwestern region of Romania is ranked last with about half a million holdings, while the leading regions (Germany, France, Austria) has ranked as the best in analysis. Surprisingly, in the Czech Republic they have recognized this advantage, resulting in a small number of farms that are over 150 ha in average size and occupies the 1st place in this analysis. However, if holdings larger than 100 ha are the subject of a comparative analysis, Vojvodina positively displays its comparative advantage and it is at the second place, between the Central region of France and Germany's Brandenburg. Farms in the region of Vojvodina (over $100 \mathrm{ha}$ ) are primarily cultivated by corn and wheat. On the other hand, if we observe the average size of farms, the region of Vojvodina with the average of 11.4 ha is located in the middle of the selected regions. According to this parameter, the regions of Brandenburg in Germany, Central Bohemian Region and the French Central region have the most important advantage.

Table 1. Parameters of comparative analysis for selected regions of EU and Vojvodina

\begin{tabular}{|c|c|c|c|c|c|c|c|c|c|c|c|}
\hline \multirow[b]{2}{*}{ Parameters } & \multicolumn{10}{|c|}{ Region EU (NUTS-2) } & \multirow{2}{*}{$\begin{array}{l}\stackrel{0}{\subseteq} \\
: \frac{1}{0} \\
\frac{2}{0} \\
>\end{array}$} \\
\hline & 刃ુ & 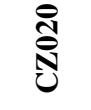 & 空 & กิ้ & 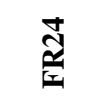 & $\begin{array}{l}\text { ષ્ } \\
\text { 号 }\end{array}$ & $\underline{\underline{\theta}}$ & $\stackrel{m}{\stackrel{9}{\mid}}$ & ลี & $\stackrel{7}{\bar{g}}$ & \\
\hline Area (mill. ha) & 1,98 & 1,10 & 2,95 & 1,88 & 3,92 & 3,19 & 1,83 & 1,83 & 1,92 & 3,42 & 2,15 \\
\hline Population (million) & 1,1 & 1,3 & 2,5 & 1,9 & 2,5 & 2,9 & 4,9 & 1,3 & 1,7 & 2,6 & 1,9 \\
\hline Arable land (000 ha) & 360 & 279 & 514 & 352 & 1.250 & 486 & 403 & 627 & 79 & 477 & 1.466 \\
\hline $\begin{array}{c}\text { Share of arable land in total } \\
(\%)\end{array}$ & 28,3 & 49,7 & 45,3 & 39,0 & 58,6 & 25,4 & 44,9 & 52,2 & 23,8 & 57,4 & 73,4 \\
\hline $\begin{array}{c}\text { Cereal production } 2014 \\
\text { (million t) }\end{array}$ & 1,44 & 1,79 & 3,28 & 1,49 & 8,80 & 2,96 & 3,50 & 3,32 & 0,79 & 1,96 & 5,70 \\
\hline $\begin{array}{c}\text { Average cereal production } \\
2014\left(\mathrm{t} \mathrm{ha}^{-1}\right)\end{array}$ & 2,57 & 3,27 & 2,46 & 2,03 & 3,83 & 3,65 & 4,27 & 3,47 & 1,73 & 1,00 & 3,95 \\
\hline Number of LSU $2013(000)$ & 183 & 243 & 736 & 337 & 678 & 778 & 1.366 & 649 & 526 & 720 & 598 \\
\hline $\begin{array}{c}\text { Animal production } 2015 \\
\text { (000 cattle) }\end{array}$ & 105,5 & 146,6 & 561,9 & 181,3 & 628,0 & 423,1 & 831,3 & 169,0 & 322,9 & 359,2 & 247,1 \\
\hline $\begin{array}{c}\text { Number of households } \\
2013(000)\end{array}$ & 36,8 & 3,5 & 5,4 & 100,4 & 23,2 & 120,4 & 85,2 & 106,4 & 30,7 & 499,9 & 147,6 \\
\hline $\begin{array}{c}\text { Number of holdings over } \\
\text { 100ha }\end{array}$ & 1.250 & 810 & 2.100 & 360 & 10.410 & 1.000 & 860 & 1.680 & 140 & 1.380 & 5.244 \\
\hline $\begin{array}{l}\text { SO of holdings } 2013 \\
\text { (million } €)\end{array}$ & 601 & 767 & 2.103 & 1.502 & 3.550 & 1.748 & 5.388 & 1.427 & 1.110 & 1.584 & 1.776 \\
\hline $\begin{array}{l}\text { Holdings that produce } \\
\text { renewable energy }\end{array}$ & 0 & 30 & 270 & 10 & 60 & - & 160 & 10 & 990 & 0 & - \\
\hline $\begin{array}{l}\text { Average size of households } \\
\text { (ha) }\end{array}$ & 12,8 & 183,0 & 237,6 & 6,3 & 92,2 & 7,0 & 6,8 & 8,7 & 12,0 & 3,4 & 11,4 \\
\hline
\end{tabular}

Source: Eurostat, The Statistical Office of Serbia, Croatian Bureau of statistics

If we look at the total production value of holdings in a particular region called Standard Output (SO), which represents the annual sum of the cash value of agricultural holdings production, the Vojvodina region with 1776 million of euros is remarkably ranked fourth in the comparative analysis of the selected regions.

Development of holdings' production in EU countries has been aimed at using agricultural residues for energy generation. European statistics, as well as the competent institutions of the Republic of Serbia, did not have the data for Croatian and Serbian regions for this parameter during the research period. 
The Republic of Serbia, and primarily the region of Vojvodina, has favorable natural conditions for the development of animal husbandry, owing to available high quality agricultural land and significant unused facilities for keeping livestock, left over from the years that preceded transition and privatization. Although these facts are in favor of the development of animal husbandry, this branch has been recording negative trends for more than 20 years. Number of livestock unit, which should be around the optimal 1 livestock unit ha ${ }^{-1}$, in Serbia is at around 0.3. According to The Statistical Office of the Republic of Serbia, number of livestock unit in 2015. in Vojvodina was about 0,6 millions. A large number of small manufacturers primarily engaged in production for their own use, is still predominant, which prevents intensive development of animal husbandry. In cattle raising, the most important branch of animal husbandry, herd size of 1-2 livestock units represents about $70 \%$ of farms in our country. Households with less than 10 dairy cows make up 95\% of the total number of farms, while those with over 30 cows account for merely $0.2 \%$ of the total number of farms. The average number of cattle in Serbia has been in continuous decline compared to the 80's of the last century, and this is the worst indicator of the situation in our animal husbandry activities. However, in Vojvodina, the number of cattle in 2015 compared to 2001 increased by 15\%. According to these criteria, the region of Vojvodina takes seventh place.

Based on all results of the study, it is evident that Vojvodina takes significantly fifth place, between some developed regions of EU - Veneto and Hungarian Low Land. Intensive animal husbandry is a parameter of developed agricultural activities. Since it is still on a significantly low level, it can be concluded that efforts should be concentrated on instruments that will lead to the development of this industry, resulting in figures reminiscent of those in the 80's, when the number of livestock was much higher than today.

Based on analysis of each indicator, comparing the results for selected regions by ranking, the following results were obtained and presented in the next table (Table 2).

Table 2. Total rank of selected regions

\begin{tabular}{|c|c|c|c|c|c|c|c|c|c|c|c|}
\hline & FR & DE & CZ & ITD & Vojvodina & HU & BG & HR & AT & EL & RO \\
& $\mathbf{2 4}$ & $\mathbf{4}$ & $\mathbf{0 2 0}$ & $\mathbf{3}$ & $\mathbf{3 4}$ & $\mathbf{0 4}$ & $\mathbf{2 2}$ & $\mathbf{5 2}$ & $\mathbf{1 1}$ \\
\hline Rank & 1 & 2 & 3 & 4 & 5 & 6 & 7 & 8 & 9 & 10 & 11 \\
\hline $\begin{array}{c}\text { Borda count } \\
\text { points }\end{array}$ & 97 & 91 & 74 & 68 & 66 & 64 & 60 & 58 & 57 & 50 & 47 \\
\hline
\end{tabular}

Source: author's own calculations

Based on obtained results, it can be concluded that Vojvodina occupies an important position among the selected regions of the European Union, in terms of the potential of agricultural biomass, since it is ranked fifth with a total sum of 66 points, after bigger and more developed regions: Central region of France, Brandenburg, Central Bohemian region, and Veneto.

\section{CONCLUSION}

Based on the results obtained in this study, it can be concluded that the region of Vojvodina has significant biomass potentials from agricultural production. After interpreting the research results, the manner of implementing biomass potentials through investments in plants for biomass processing and energy generation on the territory of Vojvodina, can be established.

Energy independence and energy secure supply represents an important factor in social and economic stability of the economy, whereas the development of the domestic energy market in Serbia, along with attracting new investments, is a key factor in achieving a competitive national economy. By using its own biomass, along with other types of renewable energy, Serbia can increase its energy independence. The above activities must be accompanied by financial capacity of government institutions and organizations for financing energy efficiency measures, development of production, and using modern production technologies and equipment. Previous research in this field shows that in the majority of cases in Serbia, production costs of bio-energy per unit are greater than energy prices prevailing in the market, which begs the question of whether investing in plants for biomass processing is economically justified. Due to the above reasons, generation of energy from renewable sources has been supported by the state through various forms of incentives, benefits and subsidies (feed-in tariffs).

Previous negligible use of biomass has primarily been caused by a low energy value of biomass per unit of transport volume and prominent spatial dispersion. It is necessary to analyze not only the economic, but also the environmental and social effects that the development of this branch of economy can have on local communities, especially those located in distinctly rural areas. 


\section{REFERENCES}

BRKIĆ M, TEŠIĆ M, FURMAN T, MARTINOV M, JANIĆ T. Potencijali i mogućnosti briketiranja i peletiranja otpadne biomase na teritoriji pokrajine Vojvodine. Pokrajinski sekretarijat za energetiku i tehnološki razvoj, Novi Sad, 2007.

BRKIĆ M, JANIĆ T. Nova procena vrsta i količina biomasa Vojvodine za proizvodnju energije. Savremena poljoprivredna tehnika. Vol. 36, 2: 178-188, 2010.

BRKIĆ M, JANIĆ T. Potencijalne količine biomase za proizvodnju energije u Srbiji. Savremena poljoprivredna tehnika.Vol. 37, 3: 225-234, 2011.

EUROPEAN PARLIAMENT AND OF THE COUNCI Directive 96/61/EC Directive 2001/77/EC, Directive 2003/30/EC, Directive 2009/28/EC, Directive 2003/54/EC, Directive 2003/55/EC of the European parliament and of the Council, The Kyoto Protocol

EUROSTAT 2017, web: www.ec.europa.eu/eurostat/web/products-datasets/-/tsdcc310

FORGY EW. Cluster analysis of multivariate data: efficiency versus interpretability of classifications. Biometrics, Vol. 21: 768769, 1965.

GULAN B. Stočarstvo Srbije, Makroekonomija, 20.08. 2016. web: www.makroekonomija.org/0-branislav-gulan/stocarstvosrbije-2016/

GUTZLER C, HELMING K, BALLA D, DANNOVWSKI R, DEUMLICH D, GLEMNITZ M, KNIERIM A, MIRSCHEL W, NENDEL C, PAUL C, SIEBER S, STACHOW U, STARICK A, WIELAND R, WURBS A, ZANDER P. Agricultural land use changes - a scenario-based sustainability impact assessment for Brandenburg, Germany, Ecological Indicators, Vol. 48: 505-517, 2015.

LEWANDOWSKIA I, WEGERB J, VAN HOOIJDONKA A, HAVLICKOVAB K, VAN DAMA J, FAAIJA A. The potential biomass for energy production in the Czech Republic. Biomass and Bioenergy, Vol. 30: 405-421, 2005.

LLOYD SP. Least squares quantization in Pcm. Ieee Transactions on Information Theory, Vol. 28, 2:129-137, 1982.

MACQUEEN J. Some methods for classification and analysis of multivariate observations, Fifth Berkeley Symposium on Mathematical Statistics and Probability, University of California, Press, Vol.1: 281-297, 1967.

PARAUŠIĆ V, CVIJANOVIĆ D. Ekonomska veličina poljoprivrednih gazdinstava u Srbiji i preporuka mera za njihovo osnaživanje. Zbornik radova. Republički zavod za statistiku, 25-62, 2014.

WEI WEN W. Beyond travel \& tourism competitiveness ranking using DEA, GST, ANN and Borda count. Expert Systems with Applications, vol. 38, 10: 12974-12982 2010.

ZEKIĆ V, TICA N. Valorizacija vrednosti slame strnih žita. Agroekonomika. Vol. 36: 187-198, 2007.

EUROSTAt: www.ec.europa.eu/eurostat/web/products-datasets/-/tsdcc310

www.ec.europa.eu/eurostat/statistics-explained/index.php/Energy_production_and_imports, file YB17.png

EUROSTAt: www.ec.europa.eu/eurostat/statistics-explained/index.php/Agriculture_statistics_at_regional_level

DRŽAVNI ZAVOD ZA STATISTIKU HRVATSKE : www.dzs.hr/Hrv/system/stat_databases.htm

EUROSTAT: Nomenclature of Teritorrial Units for Statistics, NUTS - Statistical regions of Europe

OFFICIAL GAZETE RS 2016 ; Uredba o podsticajnim merama za proizvodnju električne energije iz obnovljivih izvora i iz visokoefikanse kombinovane proizvodnje električne i toplotne energije, Vlada Republike Srbije, „Sl. glasnik RS“, br. 56/2016.

OFFICIAL GAZETE, Vlada Republike Srbije,Uredba o nomenklaturi statističkih teritorijalnih jedinica, Sl. glasnik RS", 109/09, $46 / 10$

REPUBLIČKI ZAVOD ZA STATISTIKU, Revizija vremenskih serija statistika poljoprivrede, ISSN 1451-0456, Beograd, Srbija, 2015. 


\title{
POTENCIJALI POLJOPRIVREDNE BIOMASE: KOMPARATIVNI PREGLED ODABRANIH REGIONA EU I REGIONA VOJVODINE
}

\author{
Petrana ODAVIĆ, Dragan MILIĆ, Vladislav ZEKIĆ, Nedeljko TICA
}

Izvod Obzirom da su se države članice EU do 2020. godine obavezale na smanjenje emisija gasova staklene bašte za $20 \%$ ispod nivoa iz 1990. godine i da iskazuju visoku uvoznu zavisnost od nafte i naftnih derivata, što uzrokuje nestabilnost snabdevanja energijom, sve više se daje prednost obnovljivim izvorima energije. S obzirom na tekući pretpristupni proces Republike Srbije ka EU, kako bi se utvrdila sposobnost zemlje da poveća udeo korišćenja energije iz obnovljivih izvora, u ovom radu izvršeno je grupisanje odabranih regiona u EU-28, nakon čega je izvršena komparativna analiza regiona u smislu potencijala poljoprivredne biomase, u cilju generisanja energije.

Cilj ovog rada je da se utvrdi na kom nivou se nalazi region Vojvodine u odnosu na deset odabranih regiona EU po osnovu parametara koji utiču na potencijal za korišćenje obnovljive energije, pre svega ostataka iz poljoprivrede. Primenom metoda k-srednjih vrednosti, metoda borda i komparativne analize, a na osnovu emprijiskih podataka, rezultati su pokazali je da region Vojvodine zauzima u proseku značajno 5. mesto. Po učešću poljoprivrenog zemljišta nalazi se na 1. mestu, a po proizvodnji žitarica i ukupnom broju gazdinstava iznad 100 ha veličine na 2. mestu. Može se zaključiti da Vojvodina predstavlja poljoprivredno područje sa velikim količinama biljnih ostataka, prvenstveno onih preostalih od žetve, što predstavlja značajan potencijal za proizvodnju energije iz poljoprivredne biomase.

Ključne reči: obnovljiva energija, biomasa, potencijali, komparativna analiza

Received / Primljen: 20.05.2017. Accepted / Prihvaćen: 20.07.2017. 